\title{
THEORETICAL STUDY OF (RS) - (4-BROMOPHENYL) (PYRIDINE-2YL) METHANOL USING DENSITY FUNCTIONAL THEORY
}

\section{SANJEEV KUMAR TRIVEDI}

Department of Physics, Mumtaz P. G. College, Lucknow University, Lucknow

At B3LYP/6-311+G (d,p) level, a theoretical study of $(\mathrm{RS})-(4-b r o m o p h e n y l)$ (pyridine-2yl) methanol was carried out using density functional theory (DFT). Calculation has also been made by theoretical IR and normal mode analysis of title compound. To understand the molecules' active sites, which are under study, the structure activity relationship based on the study of molecular electrostatic potential map of (RS)-(4-bromophenyl) (pyridine-2yl) methanol and frontier orbital gap was used.
\end{abstract}

KEYWORDS: Density Functional Theory, Vibrational Analysis, HOMO-LUMO \& MESP

Received: Aug 25, 2017; Accepted: Sep 18, 2017; Published: Oct 21, 2017; Paper Id.: IJPROCT20172

\section{INTRODUCTION}

The diphenyl methanols, $\mathrm{RPh} 2 \mathrm{COH}$, exhibit a very rich diversity of supra molecular arrangements, including isolated molecules, hydrogen-bonded dimers, trimers, tetramers and hexamers as well as continuous hydrogen-bonded chains [1]. It is therefore of considerable interest to investigate the influence of an addition potential acceptor of hydrogen bonds as achieved. The vibrational spectroscopic analysis is known to provide immensely invaluable molecular structure elucidation in synergy with quantum chemical calculations. In order to obtain a complete description of molecular dynamics, vibrational wave number calculations along with the normal mode analysis have been carried out at the DFT level employing the basis set $6-311+G(d, p)$. The optimized geometry of molecule under investigation and its molecular properties such as equilibrium energy, frontier orbital energy gap and molecular electrostatic potential energy map, have also been used to understand the properties and active sites of the molecule.

Within the framework of the density functional theory (DFT) [2], a quantum chemical study of the (RS)(4-bromophenyl) (pyridine-2yl) methanol has been performed with Becke's three-parameter hybrid exchange functional [3] with Lee-Yang-Parr correlation functional (B3LYP) [4,5] and engaging 6-311 ++ G(d, p) basis set using the Gaussian 09 program package [6]. A scaling factor of 0.9679 has been applied [7, 8] as the DFT hybrid B3LYP functional appears to overestimate the fundamental normal modes of vibration. By combining the results of symmetry considerations, Gauss view 5 program [9] and the VEDA 4 program [10], the vibrational wave number assignment has been carried out. Figure 2 shows the calculation of IR spectra.

\section{RESULT AND DISCUSSION}

Molecular Geometry Optimization and Energies

For the calculation of the compound's molecular properties using DFT at the B3LYP level, with the 
$6311+\mathrm{G}(\mathrm{d}, \mathrm{p})$ basis set, the geometry of the title compound has been optimized. The optimized geometry of molecule (Figure 1) that is under study is confirmed to be located at the local true minima on potential energy surface, as the calculated vibrational spectra contains no imaginary wave number. The optimized structural parameters like bond angles, bond lengths and dihedral angles of title compound are shown in the Table 1 . The (C - $\mathrm{O})$ bond lengths $1.427 \AA$ is seen to be close to the standard ester $\mathrm{C}-\mathrm{O}$ bond lengths $[11,12]$. These calculated bond angles and bond length are found to be in full agreement with those standard bond angles and bond lengths.

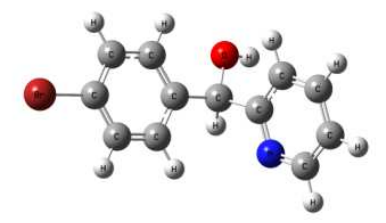

Figure 1: Optimized Geometry of (RS)-(4-Bromophenyl) (Pyridine-2yl) Methanol

Table 1: Optimize Parameters (Bond Length and Bond Angle) of (RS)-(4-Bromophenyl) (Pyridine-2yl) Methanol Calculated at B3LYP/6311+G (d, p) Level

\begin{tabular}{|c|c|c|c|}
\hline Parameter & Bond Length $(\AA)$ & Parameter & \multicolumn{1}{|c|}{ Bond Angle (Degree) } \\
\hline C1-H2 & 1.0957 & O3-C1-C5 & 108.3696 \\
\hline C1-O3 & 1.4272 & O3-C1-C17 & 111.7021 \\
\hline C1-C5 & 1.5224 & C5-C1-C17 & 111.3161 \\
\hline C1-C17 & 1.5281 & C1-O3-H4 & 108.3242 \\
\hline O3-H4 & 0.9625 & C1-C5-C6 & 121.5308 \\
\hline C5-C6 & 1.3951 & C1-C5-C14 & 119.4787 \\
\hline C5-C14 & 1.3988 & C6-C5-C14 & 118.9899 \\
\hline C6-H7 & 1.0819 & C5-C6-H7 & 119.5374 \\
\hline C6-C8 & 1.3948 & C5-C6-C8 & 120.67 \\
\hline C8-H9 & 1.0827 & H7-C6-C8 & 119.7884 \\
\hline C10-C10 & 1.3891 & C6-C8-H9 & 120.5581 \\
\hline C10-C12 & 1.7614 & C6-C8-C10 & 119.3087 \\
\hline C12-H13 & 1.3919 & H9-C8-C10 & 120.1328 \\
\hline C12-C14 & 1.0825 & C8-C10-C111 & 119.5459 \\
\hline C14-H15 & 1.3912 & C8-C10-C12 & 121.0331 \\
\hline N16-C17 & 1.0844 & C111-C10-C12 & 119.4206 \\
\hline N16-C24 & 1.3374 & C10-C12-H13 & 120.1997 \\
\hline C17-C18 & 1.3379 & C10-C12-H14 & 119.0957 \\
\hline C18-H19 & 1.3982 & H13-C12-C14 & 120.7044 \\
\hline C18-C20 & 1.0828 & C5-C14-C12 & 120.9019 \\
\hline C20-H21 & 1.3897 & C5-C14-H15 & 119.6989 \\
\hline C20-C22 & 1.0844 & C12-C14-H15 & 119.3986 \\
\hline C22-H23 & 1.3935 & C17-N16-C24 & 118.0385 \\
\hline C22-C24 & 1.0834 & C1-C17-N16 & 115.9829 \\
\hline H2-C1-O3 & 1.3915 & C1-C17-C18 & 121.2471 \\
\hline C18-C20-H21 & 1.0863 & N16-C17-C18 & 122.7627 \\
\hline C18-C20-C22 & 110.4387 & C17-C18-H19 & 119.8617 \\
\hline & 120.437 & H2-C1-C17-C18 & 158.2201 \\
\hline & & O3-C1-C17-N16 & -143.4455 \\
\hline
\end{tabular}




\begin{tabular}{|c|c|c|c|}
\hline \multicolumn{5}{|c|}{ Table 1: Contd., } \\
\hline H21-C20-C22 & 120.6516 & O3-C1-C17-C18 & 37.5135 \\
\hline C20-C22-H23 & 121.4195 & C5-C1-C17-N16 & 95.263 \\
\hline C20-C22-C24 & 118.2013 & C5-C1-C17-C18 & -83.778 \\
\hline H23-C22-C24 & 120.3791 & C1-C5-C6-H7 & 1.2869 \\
\hline N16-C24-C22 & 123.4441 & C1-C5-C6-C8 & -179.4635 \\
\hline N16-C24-H25 & 116.0027 & C14-C5-C6-H7 & -178.983 \\
\hline C22-C24-H25 & 120.5517 & C14-C5-C6-C8 & 0.2666 \\
\hline H2-C1-O3-H4 & -55.0146 & C1-C5-C14-C12 & 179.4832 \\
\hline C5-C1-O3-H4 & -173.6015 & C1-C5-C14-H15 & -0.2326 \\
\hline C17-C1-O3-H4 & 63.4141 & C6-C5-C14-C12 & -0.2525 \\
\hline H2-C1-C5-C6 & -129.8172 & C6-C5-C14-H15 & -179.9683 \\
\hline H2-C1-C5-C14 & 50.454 & C5-C6-C8-H9 & -179.823 \\
\hline O3-C1-C5-C6 & -9.9395 & C5-C6-C8-C10 & -0.0672 \\
\hline O3-C1-C5-C14 & 170.3317 & H7-C6-C8-H9 & -0.5753 \\
\hline H19-C18-C20-C22 & 179.8281 & H9-C8-C10-C111 & -0.1622 \\
\hline H19-C18-C20-C22 & 179.8281 & H9-C8-C10-C12 & 179.6035 \\
\hline N16-C17-C18-C20 & -0.0659 & C8-C10-C12-H13 & -179.6559 \\
\hline C17-C18-C20-H21 & 179.9832 & C8-C10-C12-C14 & 0.1675 \\
\hline
\end{tabular}

\section{Vibrational Assignments}

$\mathrm{C}_{1}$ point group does not display any special symmetry and the optimized molecular structure belongs to this $\mathrm{C}_{1}$ point group. Overestimation of the vibrational waver numbers in DFT methods and ab-initio are amended either by explicit computing anharmonic correlations or by presenting a scaled field, even directly scaling the deliberated wave numbers with proper factor.

Calibration of the vibrational wave numbers is done calibrated accordingly with the scaling factor of 0.9679 for DFT at B3LYP/6311+G (d, p) level. The vibrational assignments have been done on the basis of line shape, the VEDA 4 program, relative intensities and the animation option of Gauss view 5. Figure 2 shows the theoretical IR spectrum of the title compound. Table 2 represents the scaled calculated waver numbers along with their respective dominant modes.

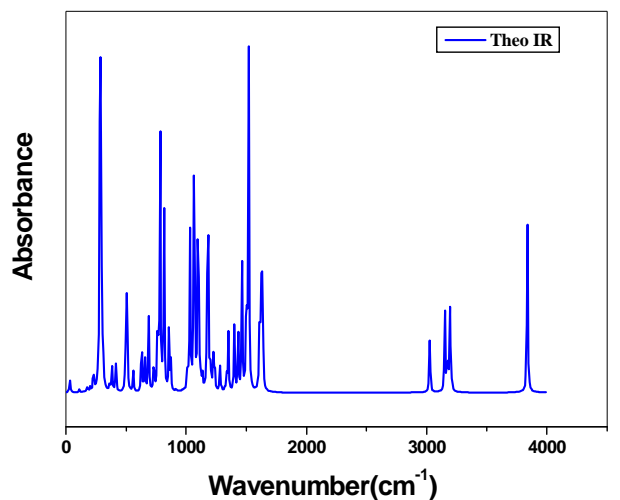

Figure 2: Theoretical IR Spectrum of (RS)-(4-Bromophenyl) (Pyridine-2yl) Methanol.

\section{O-H Vibrations}

The vibration of O-H stretching is very sensitive to hydrogen bonding. A non-hydrogen bonded hydroxyl group or a free hydroxyl group absorbs in the range $3700-3500 \mathrm{~cm}^{-1}$. The hydroxyl stretching band is reduced to $3559-3200 \mathrm{~cm}^{-1}$ region by the intra-molecular hydrogen bonding present in the system [13]. The scaled wave number calculated at 3741 
$\mathrm{cm}^{-1}$ is identified as $\mathrm{O}-\mathrm{H}$ stretching with $100 \%$ contribution to P. E. D.

\section{C-C and C-H Vibrations}

It has been observed that C-C stretching wave numbers as mixed modes in the range $1100 \mathrm{~cm}^{-1}$ to $800 \mathrm{~cm}^{-1}$. It appears that they agree well with the general appearance of $\mathrm{C}-\mathrm{H}$ and $\mathrm{C}-\mathrm{C}$ stretching modes. The $\mathrm{C}-\mathrm{C}$ pure stretching is calculated to be 1583,1575 and $1559 \mathrm{~cm}^{-1}$ which also support the previous studies. The vibration of (RS)-(4-bromophenyl) (pyridine-2yl) methanol's C-H stretching vibration has been observed in the range $3110-2929 \mathrm{~cm}^{-1}$.

\section{Ring Vibrations}

The thiophene ring spectral region predominantly comprises the $\mathrm{C}-\mathrm{H}, \mathrm{C}-\mathrm{C}, \mathrm{C}-\mathrm{Cl}, \mathrm{C}-\mathrm{S}$ and $\mathrm{C}=\mathrm{C}$ stretching, and $\mathrm{C}-\mathrm{C}-\mathrm{C}$ as well as $\mathrm{H}-\mathrm{C}-\mathrm{C}$-bending vibrations. The bands due to the ring $\mathrm{C}-\mathrm{H}$-stretching vibrations were observed as a group of partially overlapping absorptions in the region $3110-3069 \mathrm{~cm}^{-1}$ with more than $90 \%$ potential energy contribution. In the region $1600-825 \mathrm{~cm}^{-1}$, vibrations involving $\mathrm{C}-\mathrm{H}$ in-plane bending are found.

Table 2: Vibrational Analysis of Some Selected Modes of the Title Compound Calculated at the B3LYP/6311+G (d, p) Level

\begin{tabular}{|c|c|c|c|}
\hline Calculated Freq. $\left(\mathrm{cm}^{-1}\right)$ & Scaled Freq. $\left(\mathrm{cm}^{-1}\right)$ & IR Intensity & Assignment \\
\hline 3838 & 3714 & 44.7 & $v_{[(\mathrm{O} 3-\mathrm{H} 4)(100)]}$ \\
\hline 3213 & 3110 & 1.4 & $v_{[(\mathrm{C} 6-\mathrm{H} 7)(85)]}$ \\
\hline 3200 & 3097 & 3.8 & $v_{[(\mathrm{C} 18-\mathrm{H} 19)(76)]}$ \\
\hline 3199 & 3096 & 2.1 & $v_{[(\mathrm{C} 12-\mathrm{H} 13)(90)]}$ \\
\hline 3193 & 3091 & 1.2 & $v_{[(\mathrm{C} 8-\mathrm{H} 9)(85)]}$ \\
\hline 3192 & 3090 & 14.9 & $V_{\text {as }[(\mathrm{C} 18-\mathrm{H} 19)(16)+(\mathrm{C} 22-\mathrm{H} 23)(74)]}$ \\
\hline 3175 & 3073 & 1.4 & $v_{[(\mathrm{C} 14-\mathrm{H} 15)(90)]}$ \\
\hline 3172 & 3070 & 7.4 & $v_{[(\mathrm{C} 20-\mathrm{H} 21)(77)]}$ \\
\hline 3151 & 3050 & 17.6 & $v_{[(\mathrm{C} 24-\mathrm{H} 25)(93)]}$ \\
\hline 3026 & 2929 & 13.7 & $v_{[(\mathrm{C} 1-\mathrm{H} 2)(100)]}$ \\
\hline 1635 & 1583 & 12.5 & $v_{[(\mathrm{C} 14-\mathrm{C} 12)(30)]}$ \\
\hline 1627 & 1575 & 37.7 & $V_{\mathrm{as}}[(\mathrm{C} 18-\mathrm{C} 20)(25)+(\mathrm{C} 24-\mathrm{C} 22)(23)]$ \\
\hline 1611 & 1559 & 20.6 & $V_{\text {as }}[(\mathrm{N} 16-\mathrm{C} 17)(21)+(\mathrm{C} 22-\mathrm{C} 20)(18)]$ \\
\hline 1520 & 1471 & 71.0 & $\sigma[(\mathrm{H} 9-\mathrm{C} 8-\mathrm{C} 10)(18)]+\sigma[(\mathrm{H} 13-\mathrm{C} 12-\mathrm{C} 14)(19)]$ \\
\hline 1464 & 1417 & 26.7 & $\sigma[(\mathrm{H} 21-\mathrm{C} 20-\mathrm{C} 22)(25)]+\sigma[(\mathrm{H} 23-\mathrm{C} 22-\mathrm{C} 24)(32)]$ \\
\hline 1400 & 1355 & 13.8 & $\sigma[(\mathrm{H} 4-\mathrm{O} 3-\mathrm{Cl})(27)]+\sigma[(\mathrm{H} 2-\mathrm{Cl}-\mathrm{O} 3)(49)]$ \\
\hline 1351 & 1308 & 13.1 & $\sigma[(\mathrm{H} 25-\mathrm{C} 24-\mathrm{N} 16)(24)]+\tau_{\mathrm{i}[(\mathrm{H} 2-\mathrm{C} 1-\mathrm{O} 3-\mathrm{H} 4)(27)]}$ \\
\hline 1294 & 1252 & 0.8 & $v_{[(\mathrm{N} 16-\mathrm{C} 24)(47)]}$ \\
\hline 1237 & 1197 & 7.4 & $v_{[(\mathrm{N} 16-\mathrm{C} 17)(19)]+} v_{[(\mathrm{C} 1-\mathrm{C} 17)(19)]}$ \\
\hline 1181 & 1143 & 51.9 & $v_{[(\mathrm{c} 5-\mathrm{C} 1)(19)]+\sigma[(\mathrm{H} 4-\mathrm{O} 3-\mathrm{C} 1)(29)]}$ \\
\hline 1172 & 1134 & 6.1 & $\begin{array}{l}\sigma[(\mathrm{H} 19-\mathrm{C} 18-\mathrm{C} 20)(19)]+\sigma[(\mathrm{H} 21-\mathrm{C} 20-\mathrm{C} 21)(33)]+ \\
\sigma[(\mathrm{H} 23-\mathrm{C} 22-\mathrm{C} 24)(22)]\end{array}$ \\
\hline 1116 & 1080 & 4.5 & $\sigma[(\mathrm{H} 23-\mathrm{C} 22-\mathrm{C} 24)(23)]$ \\
\hline 1099 & 1064 & 52.5 & $v_{[(\mathrm{C} 12-\mathrm{C} 10)(26)]+} v_{[(\mathrm{C} 111-\mathrm{C} 10)(18)]}$ \\
\hline 1063 & 1029 & 34.9 & $v_{[(\mathrm{O} 3-\mathrm{C} 1)(47)]}$ \\
\hline 1031 & 998 & 36.2 & $\begin{array}{l}\sigma[(\mathrm{C} 10-\mathrm{C} 8-\mathrm{C} 6)(19)]+\quad \sigma[(\mathrm{C} 12-\mathrm{C} 10-\mathrm{C} 8)(20)]+\quad \sigma[(\mathrm{C} 14-\mathrm{C} 12- \\
\mathrm{C} 10)(40)]\end{array}$ \\
\hline 1013 & 980 & 1.2 & $\tau_{\mathrm{i}[(\mathrm{H} 21-\mathrm{C} 20-\mathrm{C} 22-\mathrm{C} 24)(39)]}$ \\
\hline 987 & 955 & 0.1 & 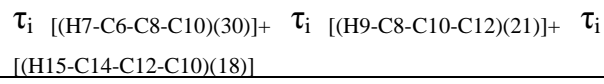 \\
\hline 983 & 951 & 0.2 & $\tau_{\mathrm{i}[(\mathrm{H} 25-\mathrm{C} 24-\mathrm{N} 16-\mathrm{C} 17)(52)]}$ \\
\hline 915 & 886 & 0.6 & $\tau_{\mathrm{i}[(\mathrm{H} 19-\mathrm{C} 18-\mathrm{C} 20-\mathrm{C} 22)(45)]+} \tau_{\mathrm{i}[(\mathrm{H} 23-\mathrm{C} 22-\mathrm{C} 24-\mathrm{N} 16)(20)]}$ \\
\hline 840 & 813 & 0.1 & $\begin{array}{l}\tau_{\mathrm{i}}[(\mathrm{H} 7-\mathrm{C} 6-\mathrm{C} 8-\mathrm{C} 10)(19)]+ \\
{[(\mathrm{H} 13-\mathrm{C} 12-\mathrm{C} 14-\mathrm{C} 5)(30)]+} \\
\tau_{\mathrm{i}[(\mathrm{H} 15-\mathrm{C} 14-\mathrm{C} 1-\mathrm{C} 12-\mathrm{C} 10)(19)]}\end{array}$ \\
\hline
\end{tabular}




\begin{tabular}{|c|c|c|l|}
\hline \multicolumn{4}{|c|}{ Table 2: Contd., } \\
\hline 763 & 739 & 18.4 & $\tau_{\mathrm{i}[(\mathrm{H} 23-\mathrm{C} 22-\mathrm{C} 24-\mathrm{N} 16)(27)]+} \tau_{\mathrm{i}[(\mathrm{C} 17-\mathrm{N} 16-\mathrm{C} 24+\mathrm{C} 22)(23)]}$ \\
\hline 732 & 708 & 7.9 & $\tau_{\mathrm{i}[(\mathrm{C} 10-\mathrm{C} 8-\mathrm{C} 6-\mathrm{C} 5)(34)]}$ \\
\hline 645 & 624 & 0.4 & $\begin{array}{l}\sigma[(\mathrm{C} 10-\mathrm{C} 8-\mathrm{C} 6)(32)]+ \\
\mathrm{C} 10)(22)]\end{array}$ \\
\hline 507 & & $\sigma(\mathrm{C} 8-\mathrm{C} 6-\mathrm{C} 5)(20)]+$ & $\sigma[(\mathrm{C} 14-\mathrm{C} 12-$ \\
\hline 414 & 491 & 31.1 & $v_{[(\mathrm{C} 111-\mathrm{C} 10)(26)]}$ \\
\hline 284 & 401 & 6.5 & $\tau_{\mathrm{i}[(\mathrm{C} 17-\mathrm{N} 16-\mathrm{C} 24-\mathrm{C} 22)(19)]+} \tau_{\mathrm{i}[(\mathrm{C} 18-\mathrm{C} 20-\mathrm{C} 22+\mathrm{C} 24)(28)]}$ \\
\hline 228 & 275 & 122.7 & $\tau_{\mathrm{i}[(\mathrm{H} 4-\mathrm{O} 3-\mathrm{C} 1-\mathrm{C} 5)(76)]}$ \\
\hline 178 & 221 & 5.1 & $\sigma[(\mathrm{C} 1-\mathrm{C} 17-\mathrm{N} 16)(37)]$ \\
\hline
\end{tabular}

\section{Electronic Properties}

Primarily acting electron donor is the highest occupied molecular orbital, HOMO. Similarly, the largely acting electron acceptor is the lowest unoccupied molecular orbital, LUMO. To characterize the kinetic stability and the chemical reactivity of the molecule, the frontier orbital energy gap is needed. Figure 3 and Figure 4 shows the 3D plots of the frontier orbital's HOMO, LUMO and the Molecular electrostatic potential map (MESP) respectively. The frontier orbital energy gap is found to be $5.302 \mathrm{eV}$.

The electrostatic potential is the energy of interaction of a positive test point charge with the nuclei and electrons of a molecule. The value of this potential mapped onto an electron iso-density surface may be engaged to differentiate the regions on the surface which are electron rich (subject to electrophilic attack) from those which are electron poor (subject to nucleophilic attack). Molecular electrostatic potential surfaces make clear that the structural similarity between two molecular does not carry over into their electrophilic/nucleophilic reactivity. Simultaneously, the resulting surface displays molecular shape, size and electrostatic potential in terms of colour grading. It is also a very useful tool that helps to investigate the correlation between the molecular structure and the physiochemical property relationship of molecules including bio molecules and drugs [14-21]. The difference in electrostatic potential created by a molecule is mainly responsible for the binding of a drug to its receptor binding sites. In general, the binding site is expected to have opposite areas of electrostatic potential. MESP plot of the title compound clearly shows that the potential swings wildly hydrogen atoms attach with oxygen atom and carbon, which bear most the brunt of positive charge (blue).

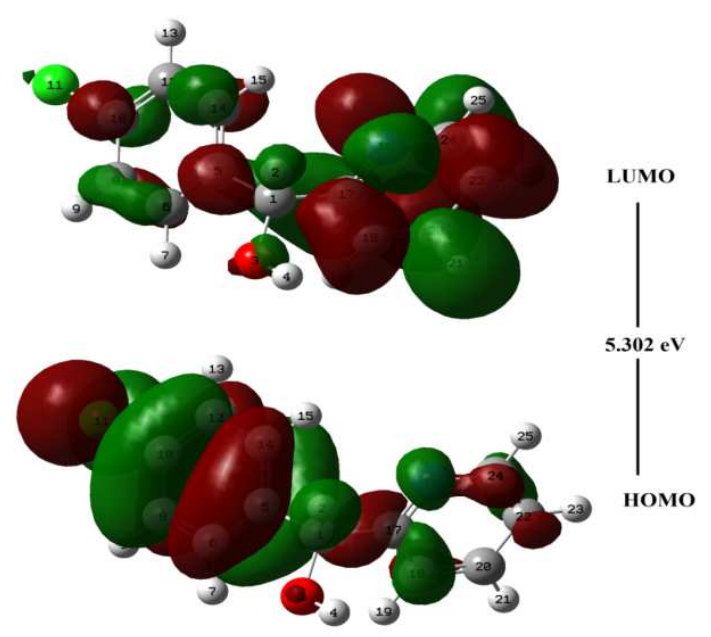

Figure 3: HOMO-LUMO Plots of (RS)-(4-Bromophenyl) (Pyridine-2yl) Methanol 


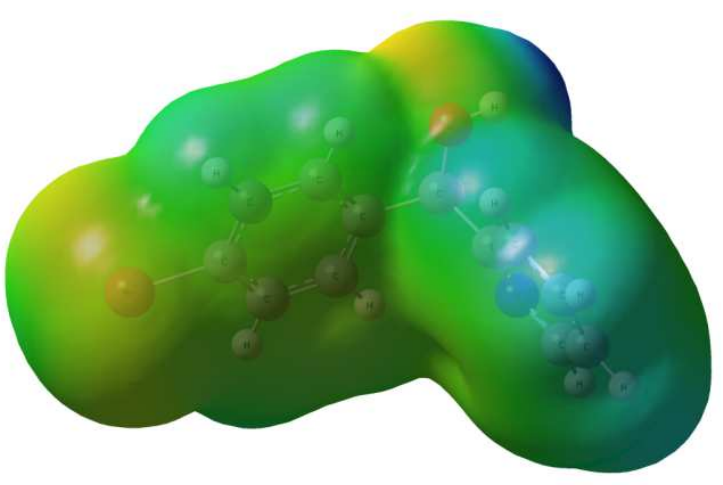

Figure 4: MESP Plot Of (RS)-(4-Bromophenyl) (Pyridine-2yl) Methanol

\section{CONCLUSIONS}

Using density functional theory, we have performed a detailed quantum chemical studies on (RS)-(4bromophenyl) (pyridine-2yl) methanol at B3LYP/6311+G (d, p) level. Analysis on vibrational spectroscopy has been performed and prominent modes of vibration are assigned and discussed. The HOMO-LUMO gap provides a degree of charge transfer interaction. These observations may stimulate further interpretations on the biological activity of (RS)-(4bromophenyl) (pyridine-2yl) methanol and related natural products.

\section{REFERENCES}

1. G. Ferguson, C. D. Carroll, C. Glidewell, C. M. Zakaria, A. J. Lough, (1995). Acta Cryst. B 51, 367-377.

2. W. Kohn, L. J. Sham, Phys. Rev. 140 (1965) Al133.

3. A. D. Becke, J. Chem. Phys. 98 (1993) 5648.

4. C. Lee, W. Yang, R. G. Parr, Phys. Rev. B37 (1988) 785.

5. B. Miehlich, A. Savin, H. Stoll, H. Preuss, Chem. Phys. Lett. 157 (1989) 200.

6. M. J. Frisch, G. W. Trucks, H. B. Schlegel, G. E. Scuseria, M. A. Robb, J. R. Cheeseman, G. Scalmani, V. Barone, B. Mennucci, G. A. Petersson, H. Nakatsuji, M. Caricato, X. Li, H. P. Hratchian, A. F. Izmaylov, J. Bloino, G. Zheng, J. L. Sonnenberg, M. Hada, M. Ehara, K. Toyota, R. Fukuda, J. Hasegawa, M. Ishida, T. Nakajima, Y. Honda, O. Kitao, H. Nakai, T. Vreven, J. A. Montgomery Jr., J. E. Peralta, F. Ogliaro, M. Bearpark, J. J. Heyd, E. Brothers, K. N. Kudin, V. N. Staroverov, R. Kobayashi, J. Normand, K. Raghavachari, A. Rendell, J. C. Burant, S. S. Iyengar, J. Tomasi, M. Cossi, N. Rega, J. M. Millam, M. Klene, J. E. Knox, J. B. Cross, V. Bakken, C. Adamo, J. Jaramillo, R. Gomperts, R. E. Stratmann, O. Yazyev, A. J. Austin, R. Cammi, C. Pomelli, J. W. Ochterski, R. L. Martin, K. Morokuma, V. G. Zakrzewski, G. A. Voth, P. Salvador, J. J. Dannenberg, S. Dapprich, A. D. Daniels, Ö. Farkas, J. B. Foresman, J. V. Ortiz, J. Cioslowski, D. J. Fox, Gaussian 09, Revision A.1, Gaussian, Inc., Wallingford CT, 2009.

7. A. P. Scott, L. Random, J. Phys. Chem. 100 (1996) 16502.

8. P. Pulay, G. Fogarasi, G. Pongor, J. E. Boggs, A. Vargha, J. Am. Chem. Soc. 105 (1983) 7037.

9. A. Frisch, H. P. Hratchian, R. D. Dennington II, T. A. Keith, John Millam, A. B. Nielsen, A. J. Holder, J. Hiscocks. Gaussian, Inc. GaussView Version 5.0., June 2009. 
10. M. H. Jamroz, Vibrational Energy Distribution Analysis: VEDA 4 Program Warsaw, Poland, 2004.

11. M. Ladd, Introduction to Physical Chemistry, third ed., Cambridge University Press, Cambridge, 1998.

12. F. H. Allen, O. Kennard, D. G. Watson, L. Brammer, A. G. Orpen, R. Taylor, J. Chem. Soc., Perkin Trans. II (1987) S1-S19.

13. M Jag. Organic Spectroscopy-Principles and Applications ( $2^{\text {nd }}$ Edition) Narosa Publishing House: New Delhi, 2001.

14. I. Fleming, Frontier Orbitals and Organic Chemical Reactions, John Wiley and 397 Sons, New York, 1976.

15. J. S. Murray, K. Sen, Molecular Electrostatic Potentials, Concepts and Applications, Elsevier, Amsterdam, 1996.

16. I. Alkorta, J. J. Perez, Int. J. Quant. Chem. 57 (1996) 123.

17. E. Scrocco, J. Tomasi, in: P. Lowdin (Ed.), Advances in Quantum Chemistry, Academic Press, NewYork, 1978.

18. F. J. Luque, M. Orozco, P. K. Bhadane, S. R. Gadre, J. Phys. Chem. 97 (1993) 9380.

19. J. Sponer, P. Hobza, Int. J. Quant. Chem. 57 (1996) 959.

20. R. K. Pathak, S. R. Gadre, J. Chem. Phys. 93 (1990) 1770.

21. S. R. Gadre, I. H. Shrivastava, J. Chem. Phys. 94 (1991) 4384. 
